BIODIK: Jurnal IImiah Pendidikan Biologi
ISSN 2580-0922 (online), ISSN 2460-2612 (print)
Volume 6, Nomor 03, Tahun 2020, Hal. 361-371
Available online at:
hIttps://online-journal.unja.ac.id/biodik

Research Article open Access

\title{
Analisis Lembar Kerja Siswa Praktikum Struktur Darah berbasis Diagram Vee
}

\section{(Analysis of Blood Structure Student's Practical Worksheet based on Diagram Vee)}

Yunni Handayanie, Sri Anggraeni, Bambang Supriatno

Universitas Pendidikan Indonesia, Bandung

Jl. Dr. Setiabudhi No.229, Cidadap, Isola, Sukasari, Kota Bandung, Jawa Barat 40154-Indonesia

Corresponding Athors: yunnihandayanie@student.upi.edu

\begin{tabular}{|c|c|}
\hline Informasi Artikel & ABSTRACT \\
\hline $\begin{array}{l}\text { Submit: } 14-06-2020 \\
\text { Diterima: } 30-08-2020 \\
\text { Dipublikasikan: } 14-09-2020\end{array}$ & $\begin{array}{l}\text { The Industrial Revolution } 4.0 \text { is a challenge for the quality of education in Indonesia. } \\
\text { One way to improve the quality of education is through practical work using student's } \\
\text { practical worksheet. Biology Practical Worksheet on Blood Structure Subject. The } \\
\text { study was a descriptive qualitative and the research subject was the student's } \\
\text { practical worksheet on blood structure. The used sampling technique was total } \\
\text { sampling, which included six student worksheets of KTSP } 2006 \text { and four student } \\
\text { worksheets of } 2013 \text { Curriculum. The used instruments were the instrument of } \\
\text { conceptual analysis and practical analysis, which were self-developed, also the } \\
\text { instrument of cognitive construction analysis based on Vee Diagram. The findings } \\
\text { show the tested worksheet includes some issues on conceptual, procedural, and } \\
\text { cognitive construction. The issue on conceptual relies on the work procedure which } \\
\text { was not aligned with the objective. The issue on practical are: 1) the difficulty on } \\
\text { object identification; 2) the recorded-data was not structured; and 3) there were no } \\
\text { safety-lab procedure. The issue on cognitive construction are: 1) the object / event } \\
\text { was not in accordance with focused-question; 2) the identified-concept was not based } \\
\text { on any principle or theory; } 3 \text { ) the notes / transformation was not in accordance with } \\
\text { the main procedure; and 4) the cognitive claim was not in accordance with concept, } \\
\text { principle, or theory. } \\
\text { Kevwords: : Student's Practical Worksheet Blood Structure. Vee Diagram }\end{array}$ \\
\hline Penerbit & ABSTRAK \\
\hline $\begin{array}{l}\text { Program Studi Pendidikan } \\
\text { Biologi, Fakultas Keguruan dan } \\
\text { Ilmu Pendidikan, Universitas } \\
\text { Jambi }\end{array}$ & $\begin{array}{l}\text { Revolusi Industri } 4.0 \text { menjadi tantangan bagi kualitas pendidikan di Indonesia. Salah } \\
\text { satu cara untuk meningkatkan kualitas pendidikan yaitu dengan kegiatan praktikum } \\
\text { menggunakan Lembar Kerja Siswa (LKS) praktikum. Penelitian ini bertujuan untuk } \\
\text { memberikan gambaran mengenai permasalahan LKS praktikum struktur darah di } \\
\text { SMA. Penelitian ini merupakan penelitian deskriptif kualitatif dan subjek penelitian ini } \\
\text { adalah LKS praktikum struktur darah. Teknik sampling yang digunakan yaitu total } \\
\text { sampling, sampel terdiri dari } 6 \text { LKS pada KTSP } 2006 \text { dan } 4 \text { LKS pada Kurikulum } \\
\text { 2013. Instrumen yang digunakan meliputi instrumen analisis konseptual dan analisis } \\
\text { praktikal yang dikembangkan oleh penulis serta instrumen analisis kontruksi } \\
\text { pengetahuan berdasarkan Diargam Vee. Hasil temuan menunjukkan LKS praktikum } \\
\text { struktur darah masih terdapat masalah pada konseptual, prosedural dan konstruksi } \\
\text { pengetahuan. Permasalahan pada konseptual yaitu langkah kerja yang tidak sesuai } \\
\text { dengan judul/tujuan. Permasalahan pada praktikal yaitu: 1) sulitnya mengidentifikasi } \\
\text { objek / fenomena; 2) perekaman data tidak terstruktur; dan 3) tidak adanya prosedur } \\
\text { safety lab. Sedangkan permasalahan pada konstruksi pengetahuan yaitu: 1) objek / } \\
\text { peristiwa tidak sesuai dengan pertanyaan fokus; 2) konsep teridentifikasi tanpa } \\
\text { prinsip dan teori; 3) catatan / transformasi tidak sesuai dengan kegiatan utama; dan } \\
\text { 4) klaim pengetahuan tidak sesuai dengan konsep, prinsip dan teori. } \\
\text { Katakunci: Lembar Kerja Siswa, Praktikum, Struktur Darah, Diagram Vee }\end{array}$ \\
\hline
\end{tabular}


This BIODIK : Jurnal IImiah Pendidikan Biologi is licensed under a CC BY-NC-SA (Creative Commons Attribution-ShareAlike 4.0 International License)

\section{PENDAHULUAN}

Revolusi Industri 4.0 merupakan salah satu konsep pengembangan pendidikan melalui pemanfaatan teknologi (Muhali, 2018). Revolusi Industri 4.0 memiliki tantangan bagi dunia pendidikan di Indonesia salah satunya bidang sains sehingga kualitas pendidikan perlu ditingkatkan (Sunarno, 2018). Salah satu cara untuk meningkatkan kualitas pendidikan yaitu melalui pembelajaran prosedural. Pengetahuan prosedural ini dapat diperoleh siswa melalui kegiatan praktikum. Kegiatan praktikum yaitu kegiatan di mana siswa memanipulasi dan mengamati objek atau fenomena secara nyata (Abraham \& Millar, 2008). Kegiatan praktikum ini adalah sebuah strategi yang mengarahkan siswa untuk menemukan suatu pengetahuan dari konsep-konsep yang diperoleh dari pengalaman langsung dalam mengamati suatu objek atau fenomena (Hamidah, et. al., 2014 dan Aisya, et. al., 2016). Guru biologi tentu sangat berperan dalam pembelajaran biologi. Pengetahuan guru biologi dalam melakukan kegiatan praktikum memiliki pengaruh kuat pada keterlibatan aktif siswa pada pembelajaran biologi (Turner, et. al., 2017). Sehingga guru biologi harus terampil dan kompeten dalam merancang, mempersiapkan dan melaksanakan pembelajaran biologi khususnya kegiatan praktikum (Fadzil \& Saat, 2020).

Kegiatan praktikum sebagai faktor kunci dalam menarik, menyemangati dan menginspirasi siswa sehingga meningkatkan minat dalam bidang sains. Kegiatan praktikum yang memiliki kualitas yang bagus dan sesuai merupakan pembelajaran yang efektif dalam bidang sains. Kegiatan praktikum itu dirasa sangat penting dalam pembelajaran karena: (1) meningkatkan kreativitas, keingintahuan dan berpikir kritis; (2) menopang dan mengilustrasikan konsep, pengetahuan, dan prinsip; (3) mendorong keterlibatan siswa dengan metode ilmiah; (4) mendorong pembelajaran aktif dan pemecahan masalah; (5) memungkinkan kerja kolaboratif; serta (6) memberikan peluang untuk mengumpulkan, menganalisis data dan menerapkan keterampilan matematika (Society of Biology, 2010).

Kegiatan praktikum ini membutuhkan sebuah pedoman yang dapat mengarahkan siswa untuk mengkonstruksi pengetahuannya berdasarkan fenomena yang muncul (Wahidah, et al., 2018). Salah satu cara untuk mengimplementasikan kegiatan praktikum yaitu menggunakan lembar kerja (Kidman, 2012). Lembar kerja atau yang biasa disebut dengan LKS (Lembar Kerja Siswa) ini mampu mengarahkan siswa untuk mengkonstruksi pengetahuan. Permasalahan terkait LKS yang beredar di lingkungan sekolah seringkali muncul. Adapun permasalahannya meliputi: (1) tujuan praktikum lebih banyak menekankan aspek kognitif daripada aspek psikomotor; (2) sebagian besar menggunakan pendekatan deduktif dengan model ekspositori; (3) prosedur praktikum meskipun rinci, beberapa di antaranya tidak 
terstruktur dan perintahnya membingungkan sehingga menimbulkan penafsiran ganda; serta (4) pemilihan materi tidak mempertimbangkan esensi, kesesuaian, kedalaman dan kompleksitasnya (Supriatno, 2007). Berdasarkan hasil observasi peneliti pada salah satu SMA, LKS yang dipakai di sekolah belum efektif sehingga kegiatan praktikum dirasa tidak maksimal. Pada LKS seringkali tujuannya tidak sesuai dengan data yang diperoleh dan objek yang diamati sulit diidentifikasi. Kegiatan praktikum yang tidak maksimal ini mengakibatkan pembelajaran menjadi tidak bermakna. Berdasarkan hal tersebut maka diperlukan LKS yang efektif dan mampu membantu siswa dalam pembelajaran yang bermakna.

Penggunaan LKS dalam pembelajaran biologi akan menumbuhkan perhatian, keinginan, minat, tekad, daya cipta, imajinasi dan kemampuan siswa (Prasetiwi \& Lbn Gaol, 2015). LKS praktikum yang dianalisis yaitu pada materi struktur darah. Pemilihan materi ini didasarkan pada tuntutan kurikulum yaitu mengaitkan struktur dengan fungsi darah yang seringkali dilupakan oleh para pembuat LKS. Praktikum ini memiliki tingkat keterampilan dan ketelitian yang tinggi sehingga diperlukan LKS yang dapat membantu siswa dalam melakukan kegiatan praktikum tersebut. Analisis LKS dilakukan berdasarkan analisis konseptual, analisis praktikal dan analisis konstruksi pengetahuan berdasarkan Diagram Vee. Diagram Vee dapat mengungkap pengetahuan yang sudah diketahui, pengetahuan yang telah didapat dan cara menganalisis data yang telah diperoleh (Novak \& Gowin, 1985). Diagram Vee juga lebih banyak menekankan pada berpikir dan melakukan aktivitas untuk mengoptimalkan pembelajaran berbasis sains (Risko, 2007).

\section{METODE PENELITIAN}

Revolusi Industri 4.0 merupakan salah satu konsep pengembangan pendidikan melalui pemanfaatan teknologi (Muhali, 2018). Revolusi Industri 4.0 memiliki tantangan bagi dunia pendidikan di Indonesia salah satunya bidang sains sehingga kualitas pendidikan perlu ditingkatkan (Sunarno, 2018). Salah satu cara untuk meningkatkan kualitas pendidikan yaitu melalui pembelajaran prosedural. Pengetahuan prosedural ini dapat diperoleh siswa melalui kegiatan praktikum. Kegiatan praktikum yaitu kegiatan di mana siswa memanipulasi dan mengamati objek atau fenomena secara nyata (Abraham \& Millar, 2008). Kegiatan praktikum ini adalah sebuah strategi yang mengarahkan siswa untuk menemukan suatu pengetahuan dari konsep-konsep yang diperoleh dari pengalaman langsung dalam mengamati suatu objek atau fenomena (Hamidah, et. al., 2014 dan Aisya, et. al., 2016). Guru biologi tentu sangat berperan dalam pembelajaran biologi. Pengetahuan guru biologi dalam melakukan kegiatan praktikum memiliki pengaruh kuat pada keterlibatan aktif siswa pada pembelajaran biologi (Turner, et. al., 2017). Sehingga guru biologi harus terampil dan kompeten dalam merancang, mempersiapkan dan melaksanakan pembelajaran biologi khususnya kegiatan praktikum (Fadzil \& Saat, 2020). 
Kegiatan praktikum sebagai faktor kunci dalam menarik, menyemangati dan menginspirasi siswa sehingga meningkatkan minat dalam bidang sains. Kegiatan praktikum yang memiliki kualitas yang bagus dan sesuai merupakan pembelajaran yang efektif dalam bidang sains. Kegiatan praktikum itu dirasa sangat penting dalam pembelajaran karena: (1) meningkatkan kreativitas, keingintahuan dan berpikir kritis; (2) menopang dan mengilustrasikan konsep, pengetahuan, dan prinsip; (3) mendorong keterlibatan siswa dengan metode ilmiah; (4) mendorong pembelajaran aktif dan pemecahan masalah; (5) memungkinkan kerja kolaboratif; serta (6) memberikan peluang untuk mengumpulkan, menganalisis data dan menerapkan keterampilan matematika (Society of Biology, 2010).

Kegiatan praktikum ini membutuhkan sebuah pedoman yang dapat mengarahkan siswa untuk mengkonstruksi pengetahuannya berdasarkan fenomena yang muncul (Wahidah, et al., 2018). Salah satu cara untuk mengimplementasikan kegiatan praktikum yaitu menggunakan lembar kerja (Kidman, 2012). Lembar kerja atau yang biasa disebut dengan LKS (Lembar Kerja Siswa) ini mampu mengarahkan siswa untuk mengkonstruksi pengetahuan. Permasalahan terkait LKS yang beredar di lingkungan sekolah seringkali muncul. Adapun permasalahannya meliputi: (1) tujuan praktikum lebih banyak menekankan aspek kognitif daripada aspek psikomotor; (2) sebagian besar menggunakan pendekatan deduktif dengan model ekspositori; (3) prosedur praktikum meskipun rinci, beberapa di antaranya tidak terstruktur dan perintahnya membingungkan sehingga menimbulkan penafsiran ganda; serta (4) pemilihan materi tidak mempertimbangkan esensi, kesesuaian, kedalaman dan kompleksitasnya (Supriatno, 2007). Berdasarkan hasil observasi peneliti pada salah satu SMA, LKS yang dipakai di sekolah belum efektif sehingga kegiatan praktikum dirasa tidak maksimal. Pada LKS seringkali tujuannya tidak sesuai dengan data yang diperoleh dan objek yang diamati sulit diidentifikasi. Kegiatan praktikum yang tidak maksimal ini mengakibatkan pembelajaran menjadi tidak bermakna. Berdasarkan hal tersebut maka diperlukan LKS yang efektif dan mampu membantu siswa dalam pembelajaran yang bermakna.

Penggunaan LKS dalam pembelajaran biologi akan menumbuhkan perhatian, keinginan, minat, tekad, daya cipta, imajinasi dan kemampuan siswa (Prasetiwi \& Lbn Gaol, 2015). LKS praktikum yang dianalisis yaitu pada materi struktur darah. Pemilihan materi ini didasarkan pada tuntutan kurikulum yaitu mengaitkan struktur dengan fungsi darah yang seringkali dilupakan oleh para pembuat LKS. Praktikum ini memiliki tingkat keterampilan dan ketelitian yang tinggi sehingga diperlukan LKS yang dapat membantu siswa dalam melakukan kegiatan praktikum tersebut. Analisis LKS dilakukan berdasarkan analisis konseptual, analisis praktikal dan analisis konstruksi pengetahuan berdasarkan Diagram Vee. Diagram Vee dapat mengungkap pengetahuan yang sudah diketahui, pengetahuan yang telah didapat dan cara menganalisis data yang telah diperoleh (Novak \& Gowin, 1985). Diagram Vee juga lebih banyak menekankan pada berpikir dan melakukan aktivitas untuk mengoptimalkan pembelajaran berbasis sains (Risko, 2007). 


\section{HASIL DAN PEMBAHASAN}

Hasil temuan menunjukkan masih terdapat permasalahan pada LKS struktur darah yang dianalisis. Permasalahan yang terjadi baik pada analisis konseptual, analisis praktikal dan analisis konstruksi pengetahuan dijelaskan sebagai berikut.

\section{Analisis Konseptual}

LKS praktikum yang dianalisis sudah menunjukkan komponen konseptual, tetapi skornya sangat bervariasi. Hampir seluruhnya LKS praktikum struktur darah mencapai skor maksimal pada indikator KD dan tingkat kognitif.

\begin{tabular}{|c|c|c|c|c|}
\hline \multirow[b]{3}{*}{ Kode LKS } & \multirow{2}{*}{\multicolumn{3}{|c|}{$\begin{array}{l}\text { Tabel } 4 \text { Hasil Analisis Konseptual } \\
\text { Indikator }\end{array}$}} & \multirow[b]{3}{*}{$\begin{array}{l}\text { Tota } \\
\text { skor }\end{array}$} \\
\hline & & & & \\
\hline & $\begin{array}{l}\text { KD } \\
\text { (Kompetensi } \\
\text { Dasar) }\end{array}$ & Langkah Kerja & $\begin{array}{l}\text { Tingkat } \\
\text { Kognitif }\end{array}$ & \\
\hline LKS 1 & 2 & 3 & 2 & 6 \\
\hline LKS 2 & 1 & 3 & 2 & 5 \\
\hline LKS 3 & 1 & 2 & 2 & 4 \\
\hline LKS 4 & 1 & 3 & 2 & 5 \\
\hline LKS 5 & 1 & 3 & 1 & 4 \\
\hline LKS 6 & 1 & 2 & 2 & 4 \\
\hline LKS 7 & 1 & 2 & 2 & 4 \\
\hline LKS 8 & 1 & 3 & 2 & 5 \\
\hline LKS 9 & 1 & 2 & 2 & 4 \\
\hline LKS 10 & 1 & 2 & 2 & 4 \\
\hline \multirow[t]{3}{*}{ Persentase } & Skor $2=90 \%$ & Skor $3=50 \%$ & Skor $2=90 \%$ & \\
\hline & Skor $1=10 \%$ & Skor $2=50 \%$ & Skor $1=10 \%$ & \\
\hline & & Skor $1=0 \%$ & & \\
\hline
\end{tabular}

Hasil temuan analisis konseptual pada setiap indikator memiliki persentase yang bervariasi. Indikator pertama yaitu mengenai KD, baik dari KTSP 2006 maupun Kurikulum 2013 menuntut untuk mengaitkan antara struktur dan fungsi darah. Hampir seluruhnya LKS praktikum struktur darah tidak sesuai dengan tuntutan KD, pada LKS ini hanya mengarahkan siswa untuk menjelaskan struktur darah tanpa mengaitkannya dengan fungsi darah. Jika kompetensi pada praktikum tidak sesuai dengan KD maka tuntutan KD tidak tercapai.

Indikator kedua yaitu langkah kerja yang harus sesuai dengan judul dan tujuan praktikum. Sebagian LKS praktikum struktur darah mencapai skor 2 yaitu langkah kerja sesuai judul tetapi tidak sesuai dengan tujuan atau langkah kerja tidak sesuai dengan judul tetapi sesuai dengan tujuan praktikum. Terdapat beberapa alasan yang membuat LKS tersebut memiliki skor 2. Pertama, tidak adanya judul yang tercantum pada LKS-3, LKS-6, LKS-7 dan LKS-10. Kedua, tidak adanya tujuan yang tercantum pada LKS-9. 
Indikator ketiga yaitu kegiatan praktikum harus sesuai dengan tingkat kognitif siswa. Hampir seluruhnya kegiatan praktikum pada LKS sudah sesuai dengan tingkat kognitif siswa SMA. Kegiatan praktikum ini bisa dilakukan oleh siswa SMA karena siswa SMA sudah mampu untuk menggunakan benda tajam seperti blood lancet dengan prosedur yang benar. Praktikum ini juga diperlukan keterampilan dan ketelitian yang tinggi.

\section{Analisis Praktikal}

LKS praktikum yang dianalisis sudah menunjukkan komponen praktikal, tetapi skornya sangat bervariasi. Hampir seluruhnya LKS praktikum struktur darah mencapai skor maksimal pada indikator alat praktikum, bahan praktikum dan langkah-langkah praktikum.

Tabel 5 Hasil Analisis Praktikal

\begin{tabular}{|c|c|c|c|c|c|c|c|}
\hline \multirow[b]{2}{*}{$\begin{array}{l}\text { Kode } \\
\text { LKS }\end{array}$} & \multicolumn{6}{|c|}{ Indikator } & \multirow[t]{2}{*}{$\begin{array}{l}\text { Total } \\
\text { skor }\end{array}$} \\
\hline & $\begin{array}{c}\text { Alat } \\
\text { Praktikum }\end{array}$ & $\begin{array}{c}\text { Bahan } \\
\text { Praktikum }\end{array}$ & $\begin{array}{l}\text { Langkah- } \\
\text { langkah } \\
\text { Praktikum }\end{array}$ & $\begin{array}{c}\text { Objek / } \\
\text { Fenomena }\end{array}$ & $\begin{array}{l}\text { Perekaman } \\
\text { Data }\end{array}$ & $\begin{array}{l}\text { Petunjuk } \\
\text { Safety Lab }\end{array}$ & \\
\hline LKS 1 & 2 & 2 & 3 & 1 & 2 & 2 & 12 \\
\hline LKS 2 & 2 & 2 & 3 & 3 & 1 & 1 & 12 \\
\hline LKS 3 & 2 & 2 & 3 & 3 & 1 & 0 & 11 \\
\hline LKS 4 & 2 & 2 & 3 & 1 & 1 & 0 & 9 \\
\hline LKS 5 & 2 & 2 & 3 & 3 & 1 & 1 & 12 \\
\hline LKS 6 & 2 & 2 & 3 & 1 & 1 & 0 & 9 \\
\hline LKS 7 & 2 & 2 & 3 & 1 & 1 & 0 & 9 \\
\hline LKS 8 & 1 & 2 & 3 & 3 & 1 & 0 & 10 \\
\hline LKS 9 & 2 & 2 & 3 & 1 & 1 & 2 & 11 \\
\hline LKS 10 & 2 & 2 & 3 & 1 & 1 & 0 & 9 \\
\hline Persentase & $\begin{array}{l}\text { Skor } 2=90 \% \\
\text { Skor } 1=10 \%\end{array}$ & $\begin{array}{l}\text { Skor 2 }= \\
100 \% \\
\text { Skor 1 }=0 \%\end{array}$ & $\begin{array}{l}\text { Skor 3 }= \\
100 \% \\
\text { Skor 2 }=0 \% \\
\text { Skor 1 }=0 \%\end{array}$ & $\begin{array}{l}\text { Skor 3 }=40 \% \\
\text { Skor 2 }=0 \% \\
\text { Skor 1 }=60 \% \\
\text { Skor } 0=0 \%\end{array}$ & $\begin{array}{l}\text { Skor 2 }=10 \% \\
\text { Skor 1 }=90 \% \\
\text { Skor } 0=0 \%\end{array}$ & $\begin{array}{l}\text { Skor 2 }=20 \% \\
\text { Skor 1 }=20 \% \\
\text { Skor 0 }=60 \%\end{array}$ & \\
\hline
\end{tabular}

Indikator pertama yaitu alat praktikum yang sesuai dengan standar sekolah. hampir seluruhnya alat yang digunakan untuk praktikum sesuai dengan standar sekolah yaitu seperti object glass, cover glass, blood lancet, mikroskop dan pipet tetes. Tetapi terdapat satu LKS yang menggunakan preparat apusan darah, alat ini mungkin tidak tersedia di sekolah karena harganya cukup mahal, sehingga alternatif lainnya yaitu membuat apusan darah segar. Indikator kedua yaitu bahan praktikum yang mudah/sulit diperoleh. Bahan yang digunakan mudah untuk ditemui dan tersedia di sekolah seperti alkohol 70\%, pewarna Giemsa / Metylen Blue, akuades, larutan Hayem dan larutan Turk. Larutan Hayem berfungsi untuk mengencerkan eritrosit dan melisiskan leukosit dan trombosit, sedangkan larutan Turk berfungsi untuk mengencerkan leukosit dan melisiskan eritrosit dan trombosit. Kedua larutan ini biasanya digunakan bersamaan dengan penggunaan haemocytometer yaitu untuk menghitung sel darah. Kedua larutan ini tidak tepat jika digunakan untuk mengamati 
struktur sel darah. Penggunaan alat dan bahan ini perlu diperhatikan karena kesalahan penggunaan alat atau bahan praktikum dapat menghambat kegiatan praktikum (Dlamini, 2008).

Indikator ketiga yaitu langkah-langkah praktikum yang terstruktur. Seluruhnya langkah kerja pada LKS praktikum yang dianalisis sudah terstruktur, tetapi terdapat beberapa langkah yang kurang jelas sehingga berpengaruh terhadap objek/fenomena. Siswa dapat menguasai langkah kerja apabila didefinisikan secara jelas atau dituangkan dalam bentuk skema, bagan, diagram atau gambar (Winkel, 1996).

Indikator keempat yaitu objek / fenomena yang muncul, sebagian LKS dapat memunculkan objek/fenomena tetapi sulit diamati. Hal ini disebabkan karena pada langkah kerja tidak ada perintah untuk mengapus darah yang berada di atas object glass sehingga sel darah yang muncul sangat menumpuk seperti pada LKS-1 pada Gambar 1. Langkah pengapusan darah ini sangat fatal apabila tidak dilakukan karena akan menyebabkan objek yang akan diamati tidak sesuai dengan keinginan. Apabila objek tidak dapat diamati maka siswa tidak dapat mendapatkan konsep dan tujuan yang diinginkan tidak tercapai. Berbeda pada LKS-2 yang terdapat perintah untuk mengapus darah, hasil uji coba terlihat bahwa sel darah sangat jelas dan mudah diamati. Metode pengapusan ini adalah metode agar pengamatan morfologi darah dibawah mikroskop menjadi lebih mudah (Fitriyaningsih, 2016).

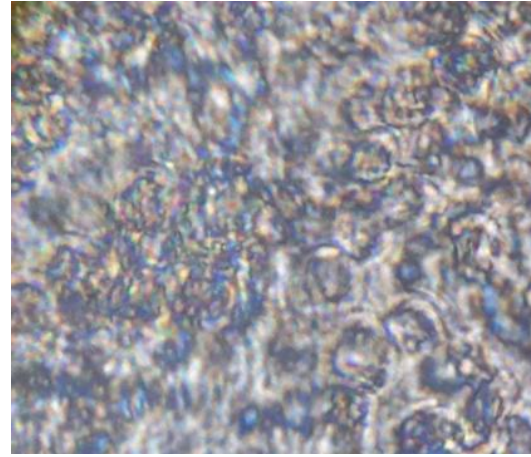

(a)

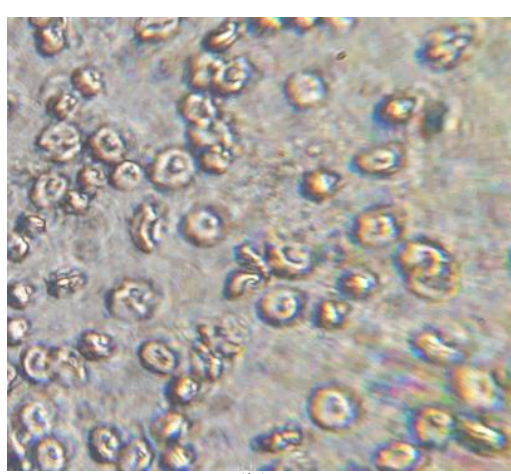

(b)

Gambar 1. Hasil Uji Coba: (a) LKS-1 dan (b) LKS-2

(Dokumentasi Pribadi, 2020)

Indikator kelima yaitu perekaman data pada LKS praktikum. Semua LKS yang dianalisis mengarahkan siswa untuk merekam data. Hampir seluruhnya LKS hanya menuntut siswa untuk menggambar komponen darah yang diamati dan membebaskan siswa untuk menyusun datanya sendiri. Berbeda dengan LKS-1 yang mencantumkan tabel untuk menuliskan data (Gambar 2). Tabel ini dapat memudahkan siswa untuk menuliskan data yang diperolehnya. 


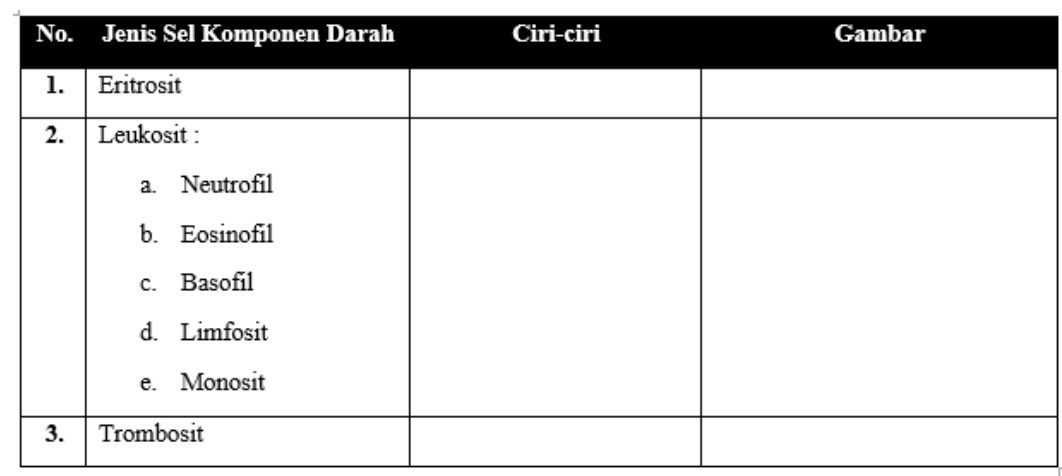

Gambar 2. Perekaman Data LKS-1

Indikator keenam yaitu prosedur safety lab. Sebagian LKS praktikum yang dianalisis tidak mencantumkan prosedur safety lab. Prosedur safety lab ini sangat diperlukan untuk menghindari kejadian yang tidak diinginkan, selain itu pada praktikum ini menggunakan benda tajam seperti blood lancet yang diperlukan kehatihatian dalam penggunaannya. LKS praktikum yang sudah mencantumkan safety lab sebanyak empat, dua di antaranya sudah tepat yaitu mengingatkan siswa agar tidak menggunakan blood lancet yang sama secara bergantian. Tetapi dua LKS lainnya hanya memunculkan prosedur safety lab secara umum, misalnya mengingatkan siswa untuk menerapkan prosedur ilmiah dan keselamatan kerja dalam praktikum. Prosedur ini tidak spesifik jika digunakan untuk praktikum struktur darah, siswa tidak akan mengerti jika hanya membaca prosedur safety lab ini.

\section{Analisis Konstruksi Pengetahuan}

LKS praktikum yang dianalisis sudah menunjukkan adanya komponen Diagram Vee, tetapi skornya sangat bervariasi. Hasil analisis konstruksi pengetahuan berdasarkan diagram Vee pada LKS struktur darah (Tabel 2) menunjukkan komponen yang umumnya sudah mencapai skor maksimal adalah komponen pertanyaan fokus. Sedangkan komponen yang lainnya seperti objek / peristiwa, konsep / prinsip/ teori dan klaim pengetahuan tidak mencapai skor maksimal. Hal ini disebabkan karena objek yang muncul sulit diidentifikasi sehingga berpengaruh terhadap konsep, prinsip, teori dan juga klaim pengetahuan. 
Tabel 6. Hasil Analisis Konstruksi Pengetahuan berdasarkan Diagram Vee

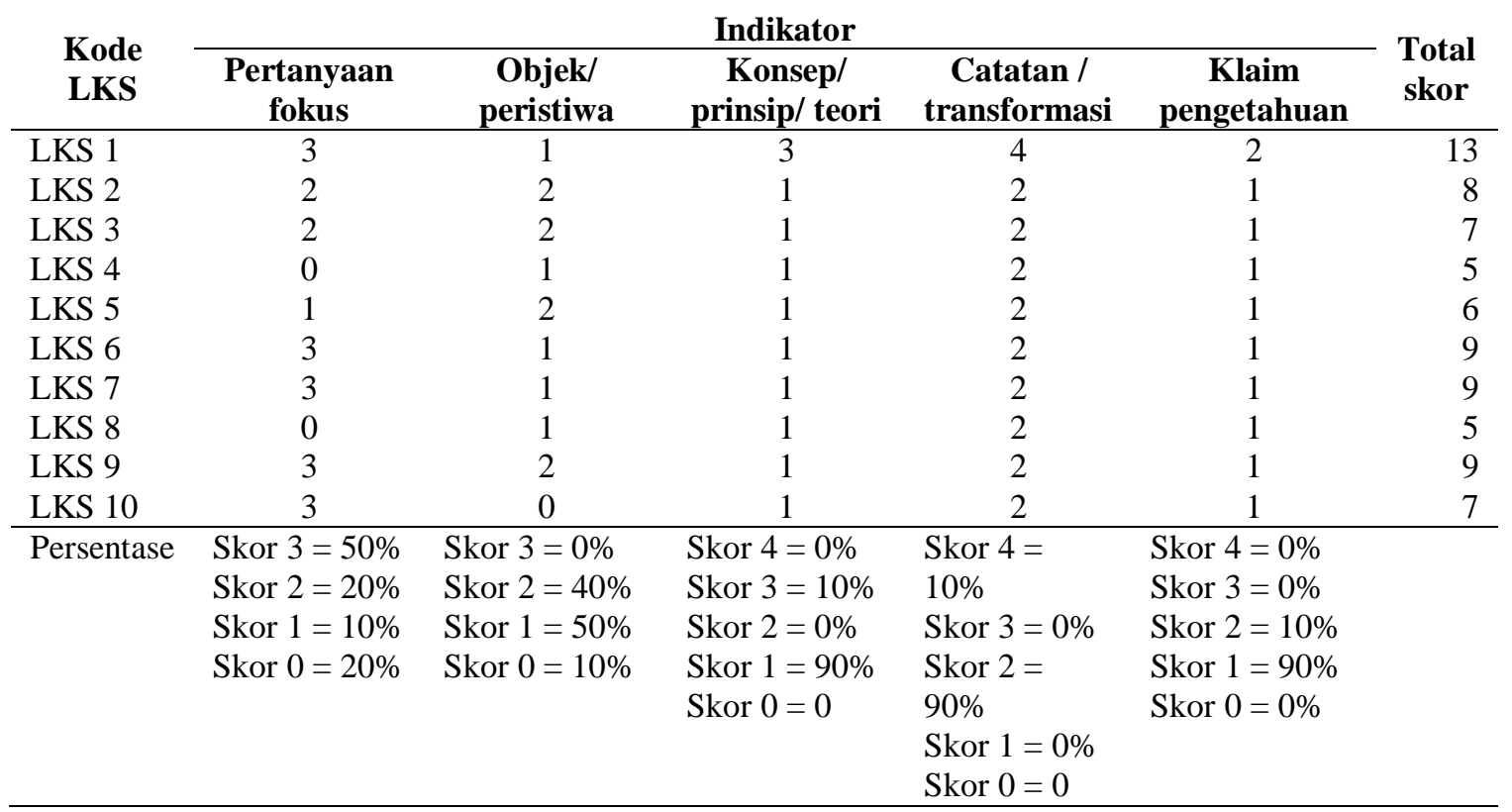

Indikator pertama yaitu pertanyaan fokus. Sebagian LKS sudah menunjukkan pertanyaan fokus dapat diidentifikasi meliputi bagian konseptual yang dapat digunakan serta mendukung peristiwa utama dan memperkuat objek. Indikator kedua yaitu objek / peristiwa pada LKS yang dianalisis tidak ada yang mencapai skor maksimal, tetapi sebagian dari LKS mencapai skor 1 yaitu peristiwa utama atau objek dapat diidentifikasi dan konsisten dengan pertanyaan fokus atau peristiwa dan objek dapat diidentifikasi tetapi tidak konsisten dengan pertanyaan fokus.

Indikator ketiga yaitu konsep, prinsip, teori. Sebagian besar LKS mencapai skor 1 yaitu konsep yang dapat diidentifikasi sedikit tetapi tanpa prinsip-prinsip serta teori. Umumnya LKS yang dianalisis hanya menanyakan terkait konsep saja misalnya seperti ciri-ciri dari eritrosit tanpa mengaitkannya dengan prinsip ataupun teori. Konsep, prinsip dan teori dapat mendukung proses pencatatan data dan transformasi data karena pemahaman terkait konsep, prinsip dan teori membantu dan mengarahkan siswa untuk mengorganisasi data yang didapatkan sehingga data yang didapatkan dapat membentuk suatu klaim pengetahuan (Wahidah et al., 2018).

Indikator keempat yaitu catatan / transformasi. Hampir seluruhnya mencapai skor 2 yaitu kegiatan pencatatan dapat diidentifikasi tetapi tidak konsisten dengan pertanyaan atau kegiatan utama. Seluruh LKS sudah ada arahan agar siswa mencatat data yang diperoleh tetapi tidak didukung oleh pertanyaan utama. Siswa dituntut untuk menggambar struktur darah berdasarkan pengamatan tapi tidak diarahkan untuk menyebutkan ciri-ciri dan fungsi dari struktur darah. Jika proses pencatatan dan tranformasi data pada praktikum tidak terjadi, maka klaim pengetahuan bisa menjadi salah atau tidak relevan dengan konsep, prinsip dan teori (Wahidah et al., 2018). Indikator kelima yaitu klaim pengetahuan yang muncul hampir seluruhnya mencapai skor 1 yaitu klaim pengetahuan tidak sesuai dengan 
bagian kiri Diagram Vee (konsep, prinsip dan teori). Klaim pengetahuan yang muncul umumnya hanya memunculkan konsep saja. Misalnya ciri-ciri leukosit tanpa mengaitkannya dengan fungsi dari leukosit.

\section{KESIMPULAN}

Analisis LKS praktikum pada penelitian ini didasarkan pada Diagram Vee. Berdasarkan hasil analisis penulis pada LKS praktikum materi struktur darah yang digunakan di SMA, dapat disimpulkan bahwa terdapat banyak permasalahan yang ditemukan pada konseptual, praktikal dan konstruksi pengetahuan. Permasalahan pada konseptual yaitu langkah kerja yang tidak sesuai dengan judul/tujuan karena judul/tujuan tidak dicantumkan. Permasalahan pada praktikal yaitu: 1) sulitnya mengidentifikasi objek/fenomena; 2) perekaman data tidak terstruktur; dan 3) tidak adanya prosedur safety lab. Sedangkan permasalahan pada konstruksi pengetahuan yaitu: 1) objek / peristiwa tidak sesuai dengan pertanyaan fokus; 2) konsep teridentifikasi tanpa prinsip dan teori; 3) catatan / transformasi tidak sesuai dengan kegiatan utama; dan 4) klaim pengetahuan tidak sesuai dengan konsep, prinsip dan teori. Solusi untuk permasalahan ini adalah memperbaiki LKS yang ada dan mempertimbangkannya berdasarkan hal konseptual, praktikal dan konstruksi pengetahuan.

\section{DAFTAR PUSTAKA}

Abraham, I., \& Millar, R. (2008). Does Practical Work Really Work? A Study of the Effectveness of Prcatical Work as a Teaching and Learning Method in School Science. International Journal of Science Education.

Aisya, N. S. M., Saefudin, Suptriatno, B., \& Anggraeni, S. (2016). Penerapan Diagram Vee dalam Model Pembelajaran Inquiry Lab dan Group Investigation untuk Meningkatkan Kemampuan Literasi Kuantitatif Siswa Kelas VII pada Materi Pencemaran Lingkungan. Proceeding Biology Education Conference, 13(1).

Dlamini, A. . (2008). Teaching of Scientific Invertigetions by Life and Natural Science Educators in Bushbuckridge. Thesis of Master Natural Science Education University of Soth Africa.

Fadzil, H. ., \& Saat, R. . (2020). Exploring Secondary School Biology Teachers' Competency in Practical Work. Jurnal Pendidikan IPA Indonesia, 9(1).

Fitriyaningsih, M. N. (2016). Perbandingan Preparat Apus Darah Hewan Berhemoglobin Dan Non Hemoglobin Sebagai Sumber Belajar Biologi. University of Muhammadiyah Malang.

Fraenkel, J. R., Wallen, N. E., \& Hyun, H. H. (2012). How to Design and Evaluate Research in Education. San Francisco.

Hamidah, A., Sari, E. N., \& Budianingsih, R. S. (2014). Persepsi Siswa tentang Kegiatan Praktikum Biologi di Laboratorium SMA Negeri se-Kota Jambi. Jurnal 
Sainmatika, 8(1).

Kidman, G. (2012). Australia at the crossroads: a review of school science practical work. Eurasia Journal of Mathematics, Science and Technology Education, $8(1), 35-47$.

Muhali. (2018). Arah Pengembangan Pendidikan Masa Kini Menurut Perspektif Revolusi Industri 4.0. Seminar Nasional Lembaga Penelitian Dan Pendidikan (LPP) Mandala.

Novak, J. ., \& Gowin, D. . (1985). Learning How to Learn. Cambridge: Cambridge University Press.

Prasetiwi, H., \& Lbn Gaol, A. (2015). Perbedaan Hasil Belajar Siswa Yang Menggunakan LKS Dan Yang Melaksanakan Praktikum Pada Sub Materi Pokok Sistem Ekskresi Manusia Kelas XI SMAN 2 Lubuk Pakam Tahun Ajaran 2014/2015. Jurnal Pelita Pendidikan, 3(4), 98-108.

Risko, M. C. A. V. . (2007). The Use Of Vee Diagrams With Third Graders As A Metacognitive Tool For Learning Science Concepts. E-Research Tennessee State Univ, 5(5), 1-19.

Society of Biology. (2010). Practical Biology Position Statement: The Importance of Practical Biology: from School to Higher Education. Retrieved from www.societyofbiology.org

Sunarno, W. (2018). Pembelajaran IPA di Era Revolusi Industri 4.0. Madiun.

Supriatno, B. (2007). Profil Lembar Kegiatan Biologi Siswa Sekolah Menengah. Proceding Seminar Nasional Jurusan Penididikan Biologi.

Turner, F., Brownhill, S., \& Wilson, E. (2017). The transfer of content knowledge in a cascade model of professional development. Teacher Development, 21(2), 175-191.

Wahidah, N. S., Supriatno, B., \& Kusumastuti, M. N. (2018). Analisis Struktur dan Kemunculan Tingkat Kognitif pada Desain Kegiatan Laboratorium Materi Fotosintesis. Indonesian Journal of Biology Education, 1(2).

Winkel, W. . (1996). Psikologi Pengajaran. Jakarta: Erlangga. 